\title{
Do the Big 4 and the Second-Tier Firms Provide Audits of Similar Independence?
}

\author{
Nedal Sawan ${ }^{1} \&$ Khaled Hamuda ${ }^{1}$ \\ ${ }^{1}$ Liverpool Business School, England \\ Correspondence: Nedal Sawan, Liverpool Business School, England. E-mail: ne2000dal@hotmail.com
}

Received: December 17, 2013 Accepted: January 9, 2014 Online Published: February 26, 2014

doi:10.5539/ass.v10n6p161

URL: http://dx.doi.org/10.5539/ass.v10n6p161

\begin{abstract}
In this paper, we examine the relation between the Big 4 and Second-tier auditors with auditor independence. Prior research suggests that the Big 4 audit firms are of higher independence than are non-Big 4 firms. The study also indicates a view that, both the public company respondents and audit firm respondents perceived the Big Four audit firms as having a higher auditor independence than other audit firms, which is consistent with findings of (Abu Bakar et al., 2005; DeAngelo, 1981b)

Data were collected by two methods, a questionnaire survey (quantitative) and a number of semi-structured interviews (qualitative) to give both triangulation and amplification. The questionnaire was analysed using both conventional comparative statistics and multivariate methods. The sample of respondents comprised three groupings: accounts managers, financial managers and internal auditors working in Libyan public companies; managing partners, partners, audit supervisors and auditors working in audit firms in Libya; and controllers working for the Libyan Association of Auditors and Accountants (LAAA).

The results of the study indicate two groups agreed that the big audit firms have enough financial resources and a large number of clients, which means they can resist client management pressure, and protect their reputation.
\end{abstract}

Keywords: audit firms, accounting profession, developing countries, auditor independence, LAAA, public companies

\section{Introduction}

Auditor independence has been the subject matter of professional and academic debate in both developed and developing countries, for a long period of time (Abu Bakar, Rahman, \& Rashid, 2005). The balance between independence and competence of the auditor and between professional relationships and personal relationships are fundamental to achieving high levels of audit quality (Richard, 2006). As studies dealing directly with auditor independence have focused on the appearance or perception of auditor independence, perceptions may not be correct, even though the use of investor perceptions may help an auditor to signal his/her quality and effect choices more effectively (see, for instance: Ferdinand, Bikki, \& Gopal, 2007; Abu Bakar et al., 2005; Shawn \& Dana, 2008).

\section{Literature Review}

The majority of experiential research that tested for an association between audit firm size and auditor independence found that there is a positive association between them (Abu Bakar et al., 2005; DeAngelo, 1981b; Shawn \& Dana, 2008). Essentially, a positive association means that the larger the audit firm size the greater the auditor's independence. They confirm that large firms are more resistant to customer pressure thus maintaining higher audit independence. In fact, it has been argued that large firms, due to their very size, may be more able and motivated to provide better audits. Thus size has been equated with independence and also performance. Consistent with that (Abu Bakar et al., 2005) reported that audit firm size appears to be the most important factor to affect the independence of an auditor.

However size may also be an important factor influencing the perceptions of the independence of the auditor (DeAngelo, 1981b; Watts \& Zimmerman, 1983). The size of audit firm is fundamental to perceived auditor independence because small firms are unable to develop appropriate financial resources, research facilities and staff to perform an examination of larger clients (Mautz \& Sharaf, 1961, p. 213). In addition small firms would face the risk of dependence on a "single major client", because the size of the firm's client portfolio is small 
relative to those of larger firms (Mautz \& Sharaf, 1961, p. 213). Audit firms with large client portfolios might have stronger incentives to protect their reputation and independence (Chow et al., 1988; DeAngelo, 1981b; Kothari et al., 1988; Lys \& Watts, 1994; Palmrose, 1988; Wallace, 1987). Thus, the issue of maintaining auditor independence is more crucial for smaller firms than larger firms.

Three solutions to these stumbling blocks to smaller audit firms were suggested by Mautz \& Sharaf (1961). These were as follows: to allow the status quo to continue with small firms providing a variety of services for their clients; to insist that they choose one of the two speciality service options (auditing and NAS) with which to supply their client, and finally to stop smaller firms from carrying out auditing services altogether on the grounds that they cannot provide auditing and NAS simultaneously and the revenue from the former service is much less than for bigger firms and so less reliable (p. 230).

According to the "deep pockets hypothesis" argued by Dye (1993), large auditing firms are said to possess greater wealth, and therefore to be exposed to higher risk in the case of law suits by creditors or investors. Dye (1993) demonstrated that richer auditors have more incentive to be diligent in their investigations of client corporations, as their greater wealth makes them more vulnerable to lawsuits. Due to the deeper pockets of large firms, they would have more to lose in the case of audit failure (Clarkson \& Simunic, 1994; Feltham, Hughes, \& Simunic, 1991).

Similar relationships between size and independence have been found by other researchers. Increased independence and less reliance on single clients with increased size were observed by Pearson (1980) and vice versa. Increased reliability of audit reports with size was reported by DeAngelo (1981b) as larger firms risked more by dishonest reporting and as a result may jeopardise their reputations.

In recent research, Choi et al. (2008) indicated that a fee premium is charged by large audit firms because they face higher legal liability costs, and hence, have more incentive to make a better effort than smaller firms. These researchers suggest that the fee premium decreases as the legal regime becomes stronger because small auditors have a higher audit failure rate than Big Four auditors, and increase audit fees significantly more to compensate for their increase in legal liability costs.

The literature on firm size has clearly highlighted that whilst different samples and methods have been used by different researchers, there is a positive relationship between firm size and audit quality. Specifically, large audit firms have more resources which they can direct to the recruitment and training process, thereby providing them with the human capability to detect and correct errors in financial statements. Moreover, as larger audit firms have reputations to preserve, they are careful to report deficiencies. That said many of the differences between large and small firms should be eliminated by the maintenance of professional standards and qualifications, and a more efficient regulatory framework.

However, an advantage of smaller size was put forward by Gul (1991), and Shockley (1982) as this could lead to more personal relationships with clients. On the other hand according to Shockley (1981), using a questionnaire to obtain his data, there was also the disadvantage of increased risk of their independence being impaired. The data also revealed that respondents from local or regional offices demonstrated contrasting views which indicated a protective feeling towards smaller firms (Shockley, 1981). This view was supported by the work of Jackson-Heard (1987) a smaller auditor tended to be more influenced by managerial pressures than larger firms. Pearson \& Ryans (1982) reported that the partners in small or medium-auditor firms disagreed with the contention that there was a positive relationship between the independence of the auditor and the size of audit firm.

According to the relationship between size of auditor and users' perception of the reliability and therefore confidence in the information content of financial reports, Goldman \& Barley (1974) disputed that corporations walk to change from small to big auditor through initial public offerings due to the high reliance of banks and financial analysts on the reports certified by big auditors.

Consistent with this argument, McKinley et al. (1985) revealed that the kind and size of the auditor were positively linked with auditor independence. He pointed out that financial reports audited by the Big Four auditors would be less expected to contain undetected fraud as compared to those audited by smaller firms.

In addition, McLennan \& Park, (2003) concluded that big auditors have greater technology and more capable workers than small auditors, and consequently have higher inducements to behave independently. As a result, according to other researchers (Davidson \& Neu, 1993; Beatty, 1989) the information content of audit reports certified and formed by big auditors are considered to be more credible and reliable than those of smaller auditors.

Based on the above theoretical arguments and empirical studies, it can be seen that size of the audit firm has an impact on perceptions of auditor independence. large audit firms were perceived to be more independent than smaller audit firms due to several reasons such as, large audit firms are not being economically dependent on one 
or few clients for their income, not having a personalised mode of client service, not having close relationship with their clients, and having numerous experienced and qualified staff that allows them to provide high audit quality. However, as Goldman \& Barlev (1974) mentioned it should not be concluded that large audit firms are immune to pressure by their clients that might impair their independence, especially when there is a high level of competition among large audit firms for clients. In addition, most of the previous studies were conducted in developed countries but little studies were done in developing countries such as Libya, where different political, economic and social systems exist which might shape the perceived impact of size of the audit firm on auditor independence.

\section{Methods and the Sampling Unit}

An aspect of the research that impacts significantly on the quality of the data that is collected is the selection of those who will participate in the research. For this reason Denscombe (2001) strongly recommends that in order to be able to use the best population sample for the research, the researchers should be able to make their own selection. Sekaran (2003, p. 265) defines population as:

"The entire group of people, events or things of interest that the researcher wishes to investigate"

For this study, the population was made up of two Libyan groups, the first being drawn from the staff of audit firms and the second being drawn from staff of industrial public companies. Within each group a further selection was made of three categories, these being auditors, managing partners and audit supervisors in the case of audit firms, and in the case of public companies, internal auditors, and financial managers and accounts managers. These specific groups were chosen since earlier researches had identified that these were the most appropriate groups to use for a study of auditor independence, since their perceptions of auditor independence were highly relevant and worth consideration. These two groups are comprised of individuals who all have professional qualifications and a high degree of training and were therefore able to make informed observations that were pertinent to this area of study. The following gives the reasons why these groups have been chosen as targets.

\subsection{Audit Firms}

who belong to the Libyan Accountants and Auditors Association (LAAA), have the right to practise as auditors and accountants, particularly, those who are registered with the General People's Committee and therefore fall under the People's control, these firms were chosen because they are employed by the government to audit the financial statements of its corporations. In this study is to meet its objective of making an examination of a number of factors that impact on perceptions of auditor independence, it is vital to be aware of audit firms' own perceptions of themselves in relation to each of the selected variables which may have an effect on auditor independence. According to the General People's Committee for the inspection and control of the People's in 2010 more than 260 firms have been registered as firms dealing with auditing and consulting.

\subsection{Industrial Public Companies}

The choice was made of Industrial public companies because they have a wide experience of dealing with auditing firms and are the longest established and biggest firms dealing with the Libyan audit market, and therefore will hold opinions relating to auditor independence since they will have contracts with external auditors who will be responsible for the auditing of their financial statements. It is therefore of significant importance to know how the staff who are part of these companies, such as internal auditors, financial managers and account managers, perceive the external auditors' independence, particular, these three classes were chosen because they have direct connection with the external auditors. The Libyan government currently owns about 121 industrial public companies.

\section{The Process of Sampling}

Once the population to be used for this study had been defined, a section of that population that could be seen as representative of the whole had to be selected, this process being known as sampling. Sekaran (2003, p. 266) defined sampling as:

"The process of selecting a sufficient number of elements from the population, so that a study of the sample and an understanding of its properties or characteristics would make it possible for us to generalise such properties or characteristics to the population elements".

Samples are used for the collection of data, rather than an entire population, because it is more manageable in terms of cost and the use of various other resources, in particular where there are a number of elements involved and they are geographically wide-spread. It is important to choose the right technique for sampling from among the range of methods that exist. Commenting on this, Collis \& Hussey, (2003) suggest that what makes a representative and good sample is one where the results that are collected from the sample can be relied upon to apply to the 
population as a whole. They also state that a good sample must be:

1) chosen at random meaning that each member within the population stands a chance of being chosen;

2) of a sufficient size to enable it to meet the needs of the investigation;

3) an unbiased sample.

Sekaran (2003) maintains that there are two main ways in which a sample may be designed. The first is probability sampling which allows for each element of a population to have a chance which is known and equal of being a selected subject, and the second is non-probability where those potentially taking part do not have a known or predetermined chance of selection. In this study probability sampling was used in order for subjects from each of the target groups, which are the staff of audit firms and the staff of public companies, to be selected. The use of a random sampling method ensures that that there is an equal probability of each person in the targeted class being selected as part of the sample. This method of sampling also makes use of non-replacement sampling so that there is no chance of choosing a specific respondent more than once. The reasons for opting to use this method are firstly that it offers greater generalizability and the sample that is most representative, and second it helps to eliminate bias which means that it is possible to make an estimation of possible sampling errors (Sekaran, 2003). Since Tripoli, the capital of Libya, Benghazi, Mosratah and Al-Zawiah are the cities where most of the financial and commercial activities of Libya take place (Khorwatt, 2006; Mahmud, 1997) these were the locations where sampling dealing with the selection of subjects from the two targeted groups took place. This was for the following reasons:

1) in excess of $80 \%$ of those audit firms registered with the General People's Committee for the People's control and inspection are located in these cities;

2) most of the economic and business activity take place here.

3 ) and these four cities have more than $85 \%$ of the industrial public companies in Libya.

Saunders et al. (2007) maintain that in order to have a good likelihood of obtaining a sampling distribution that is close to the norm, the sample size needs to be not less than $30 \%$. They also make the point that where a sample is of a large absolute size there is the likelihood that it will better represent the population from which it is drawn than would be the case with a smaller sample. However, Cohen \& Manion (1980) take the view that it is not possible to set down an exact number or percentage that needs to be used by all studies. It has been suggested by some authors that there are a number of considerations that need to be taken into account of when deciding on the size of the sample that is to be selected, such as the nature of the statistical analysis that is to be used, and how much variability is expected within the sample and the results; these considerations should be based on experience, the conventions that exist in a particular area of research in relation to what is considered an appropriate sample size, as well as the size of the whole population and issues of time and costs (Collis \& Hussey, 2003; Saunders et al., 2007).

After due consideration being given to the issues discussed above relating to the size of the sample which, in this case, will receive questionnaires, the size of the sample to be taken from each targeted population was decided to be more than $50 \%$ of the population as follows; the first segment of the questionnaire sample involved 67 public companies and 137 audit firms working in Libya. The questionnaire was given to three different classes of public company respondents, namely, internal auditors, financial managers and accounts managers; while it was also given to three different classes of audit firm respondents, namely, managing partners, audit supervisors and auditors. The total number of questionnaires distributed to the public companies was 201: 67 questionnaires of each class in the public companies mentioned above. The total number of questionnaires distributed to audit firms working in Libya was 411; 137 questionnaires to people in each position in the audit firms listed above. On the one hand, on the demand side, the three classes in public companies were chosen because they were leaders in their company's business activities and, hence, needed a monitoring mechanism to report on their performance (Jensen \& Meckling, 1976). On the supply side, three classes of audit firms were considered because they were the main subjects in the issue of interest, supplying the documentation and/or information to the shareholders to evaluate for credibility (Humphrey, 1997).

According to Saunders, et al. (2009) maintains that there are several structures for administering questionnaires: postal questionnaire, the delivery and collection approach, interviewer administered and questionnaire by telephone. In order to receive a high level of valid responses in the present case, the delivery and collection method was selected for gathering the data. The researcher distributed the questionnaire to the respondents and collected them again individually. This structure was meant to guarantee an adequate answer rate for the questionnaire survey. In addition, to establish contact for the interview phase later in the study, the delivery and collection 
method was most appropriate. Furthermore, a postal questionnaire was also sent to respondents located in far-away places outside the chosen cities. To raise the number of responses, the respondents were given the option to send their reply in a reply paid envelope, which was already included in every copy of the questionnaire that was sent out.

In the questionnaire survey, to obtain better responses, a reminder was sent to those respondents who had not yet sent in their questionnaire. This step was taken with due care and diligence, for if the researcher demonstrates inter-personal skills the respondents can become more co-operative. The total number of questionnaires completed and collected from public companies was $89 ; 28(31.5 \%)$ from the internal auditors, 31 (34.9\%) from the financial managers and $30(33.6 \%)$ from the accounts managers, while the total number of questionnaires completed and collected from the audit firms was 192 questionnaires; 46 (26.8\%) questionnaires from the managing partners, 52 (25\%) questionnaire from the audit supervisors and 94 (48.2\%) from the auditors.

\section{Results and Discussion}

\subsection{Quantitative Findings}

\subsubsection{The Size of Audit Firm and Auditor Independence}

To obtain the perspectives of the association between the size of audit firms and auditor independence, respondents from public companies staff and audit firms staff were invited to respond to the 10 questions shown in Table 1.

The analysis of differences between public companies' and audit firms' responses is also reported in Table 6.7, which reveals six significant differences at the $1 \%$ level, as measured by the Mann Whitney U test. The level of agreement of public company respondents was significantly higher than audit firm respondents for six of ten statements. In addition, the audit firm respondents were highly agreed with the first and second significant questions (questions 3 and 4) more than it was by public company respondents. Whereas, the public company respondents were highly agreed with the other significant questions (questions 5, 6, 7 and 9) more than it was by audit firm respondents. These results might be due to the differences in the experience of public companies with different size of audit firms.

The public company respondents perceived the big four audit firms as having higher levels of auditor independence than other audit firms, which is consistent with findings of (Abu Bakar et al., 2005; DeAngelo, 1981b; Gul, 1989; Kleinman et al., 1998; McKinley et al., 1985). They concluded that audit firm size appears to be the most important factor influencing independence. The reasons for this may be, inter alia,: 1) big four audit firms have greater resources at their disposal than small audit firms, 2) the big four can ensure a greater variety of clients than small audit firms, 3) the big four have more experienced and better qualified staff than other audit firms, and 4) the big four are powerful brands in their own right and are likely to be more conscious of and protective of their reputation.

Since the overall responses of public company and audit firm respondents were not completely consistent, an attempt was made to separate the determinants of responses. As regards the size of audit firm, both sample groups were analysed in two ways (a) by position of respondents and (b) by the type of audit firm, using the Kruskal Wallis test.

Both the mean and the median value was estimated in each case and reported below. The difference between the two measures of central tendency is indicative of asymmetry in the distribution of the responses and in the intensity of belief. Only in question 4 was there a significant difference (defined as $>0.5$ ) between the responses of public company staff as measured by the mean and the median. That question suggests that the intensity of belief is in favour of the view amongst public company staff that the small audit firms also have the ability to discover fraud.

Table 1. Distribution of the evaluations given by the different statements regarding the size of audit firm and audit independence

\begin{tabular}{|c|c|c|c|c|c|c|c|c|c|c|c|c|c|c|c|c|c|c|c|}
\hline \multirow[b]{2}{*}{$\begin{array}{l}\text { Statemen } \\
\text { t }\end{array}$} & \multicolumn{9}{|c|}{ Audit Firms staff (N=192) } & \multicolumn{9}{|c|}{ Public Company Staff $(\mathrm{N}=89)$} & \multirow[t]{2}{*}{$\begin{array}{l}\mathrm{Si} \\
\mathrm{g}\end{array}$} \\
\hline & $\begin{array}{l}\mathrm{S} \\
\mathrm{D} \\
\%\end{array}$ & QSD $\%$ & $\begin{array}{l}\mathrm{D} \\
\%\end{array}$ & $\begin{array}{l}\mathrm{A} \\
\%\end{array}$ & $\begin{array}{l}\text { QS } \\
\mathrm{A} \%\end{array}$ & $\begin{array}{l}\text { SA } \\
\%\end{array}$ & $\begin{array}{l}\text { Stand } \\
\text { ard } \\
\text { devia } \\
\text { tion }\end{array}$ & $\begin{array}{l}\text { Med } \\
\text { ian }\end{array}$ & $\begin{array}{l}\mathrm{Me} \\
\text { an }\end{array}$ & $\begin{array}{l}\text { SD } \\
\%\end{array}$ & $\begin{array}{l}\text { QS } \\
\text { D\% }\end{array}$ & $\begin{array}{l}\mathrm{D} \\
\%\end{array}$ & $\begin{array}{l}\mathrm{A} \\
\%\end{array}$ & $\begin{array}{l}\text { QS } \\
\mathrm{A} \%\end{array}$ & $\begin{array}{l}\text { SA } \\
\%\end{array}$ & $\begin{array}{l}\text { Stand } \\
\text { ard } \\
\text { devia } \\
\text { tion }\end{array}$ & $\begin{array}{l}\text { Med } \\
\text { ian }\end{array}$ & $\begin{array}{l}\mathrm{Me} \\
\text { an }\end{array}$ & \\
\hline $\begin{array}{l}\text { 1. The } \\
\text { size of the }\end{array}$ & $\begin{array}{l}5 . \\
2\end{array}$ & 4.7 & $\begin{array}{l}10 \\
.4\end{array}$ & $\begin{array}{l}26 \\
.0\end{array}$ & 32.8 & $\begin{array}{l}20 . \\
8\end{array}$ & 1.334 & 5.00 & $\begin{array}{l}4.3 \\
9\end{array}$ & $\begin{array}{l}10 . \\
1\end{array}$ & 9.0 & $\begin{array}{l}14 \\
.6\end{array}$ & $\begin{array}{l}20 \\
.2\end{array}$ & 27.0 & $\begin{array}{l}19 . \\
1\end{array}$ & 1.574 & 4.00 & $\begin{array}{l}4.0 \\
2\end{array}$ & \\
\hline
\end{tabular}




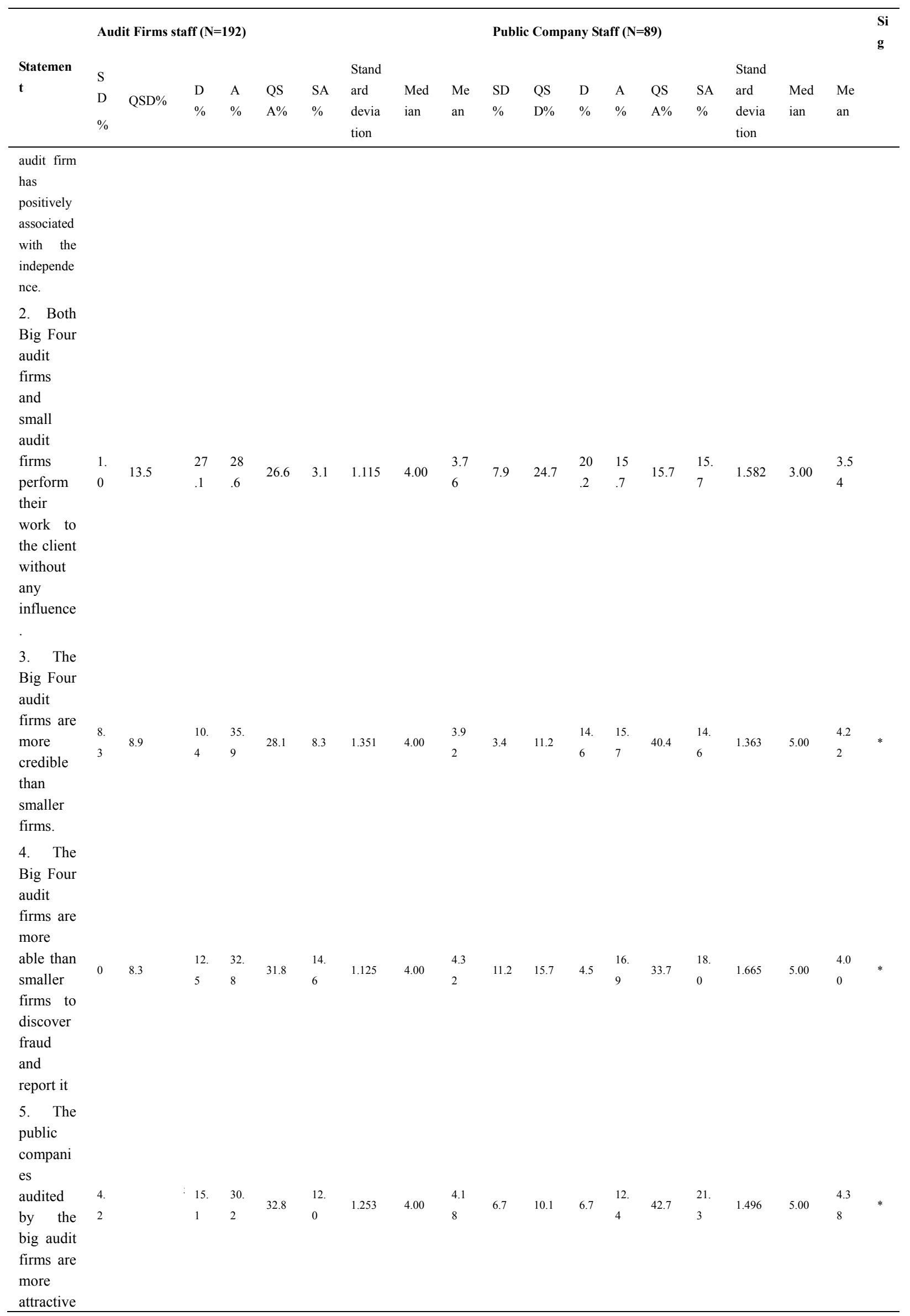




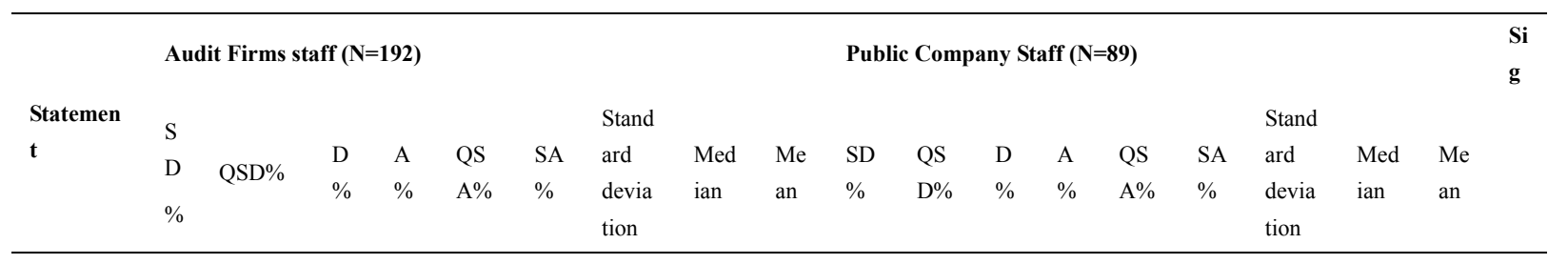

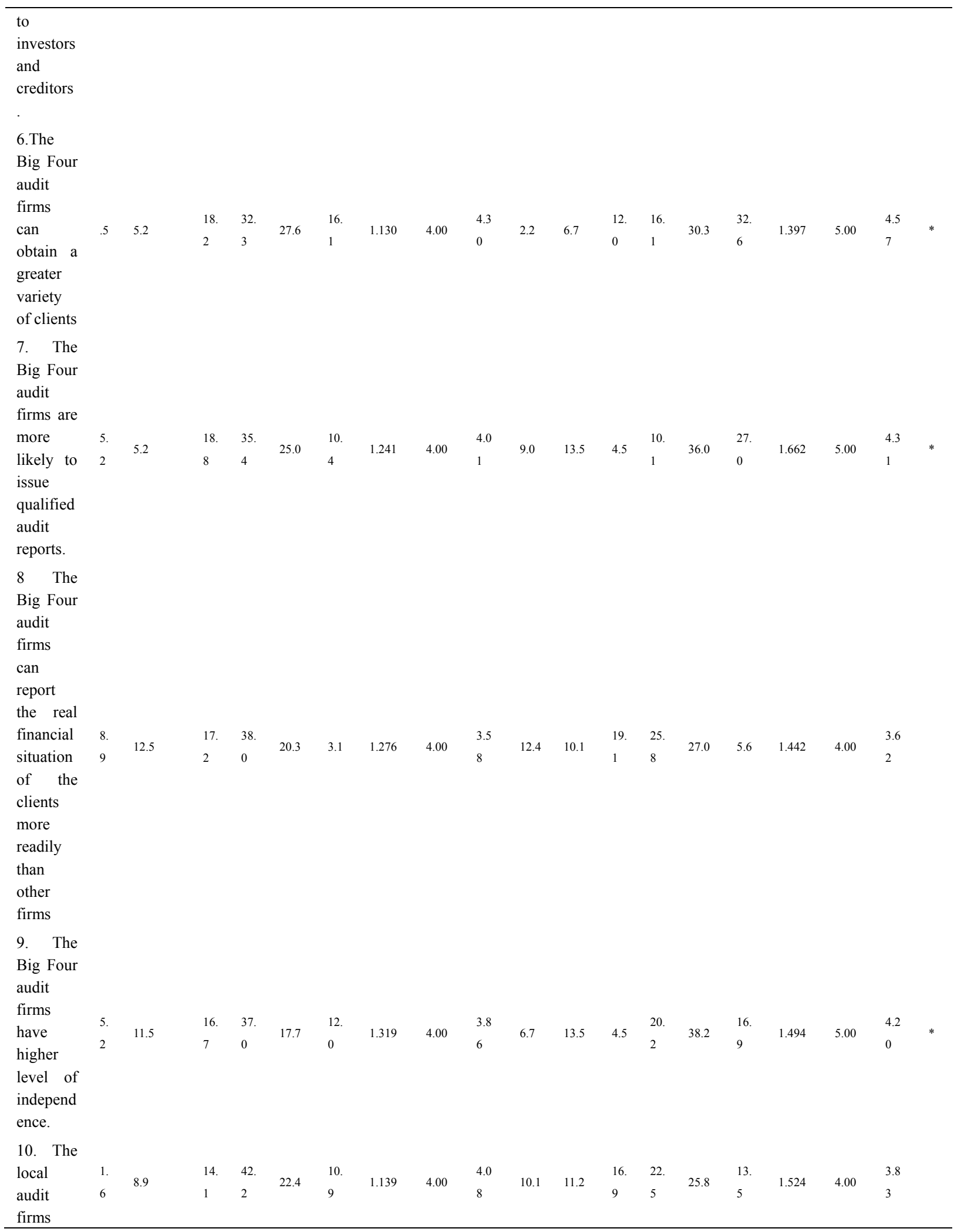




\begin{tabular}{|c|c|c|c|c|c|c|c|c|c|c|c|c|c|c|c|c|c|c|}
\hline \multirow[b]{2}{*}{$\begin{array}{l}\text { Statemen } \\
\mathbf{t}\end{array}$} & \multicolumn{8}{|c|}{ Audit Firms staff ( $N=192)$} & \multicolumn{8}{|c|}{ Public Company Staff ( $(=89)$} & & $\begin{array}{l}\mathbf{S i} \\
\mathbf{g}\end{array}$ \\
\hline & $\begin{array}{ll}\mathrm{S} & \\
\mathrm{D} & \mathrm{QSD} \% \\
\% & \end{array}$ & $\begin{array}{l}\mathrm{D} \\
\%\end{array}$ & $\begin{array}{l}\mathrm{A} \\
\%\end{array}$ & $\begin{array}{l}\text { QS } \\
\mathrm{A} \%\end{array}$ & $\begin{array}{l}\text { SA } \\
\%\end{array}$ & $\begin{array}{l}\text { Stand } \\
\text { ard } \\
\text { devia } \\
\text { tion }\end{array}$ & $\begin{array}{l}\text { Med } \\
\text { ian }\end{array}$ & $\begin{array}{l}\text { Me } \\
\text { an }\end{array}$ & $\begin{array}{l}\text { SD } \\
\%\end{array}$ & $\begin{array}{l}\text { QS } \\
\text { D\% }\end{array}$ & $\begin{array}{l}\mathrm{D} \\
\%\end{array}$ & $\begin{array}{l}\mathrm{A} \\
\%\end{array}$ & $\begin{array}{l}\text { QS } \\
\mathrm{A} \%\end{array}$ & $\begin{array}{l}\text { SA } \\
\%\end{array}$ & $\begin{array}{l}\text { Stand } \\
\text { ard } \\
\text { devia } \\
\text { tion }\end{array}$ & $\begin{array}{l}\text { Med } \\
\text { ian }\end{array}$ & $\begin{array}{l}\mathrm{Me} \\
\text { an }\end{array}$ & \\
\hline $\begin{array}{l}\text { obtain } \\
\text { lower } \\
\text { level of } \\
\text { independ } \\
\text { ence }\end{array}$ & & & & & & & & & & & & & & & & & & \\
\hline
\end{tabular}

Note: ${ }^{*}$ Indicates that the distribution of responses between the categories is significantly different at the $1 \%$ level (Mann Whitney U test).

\subsubsection{The Perceptions of Size of Audit Firm and Auditor Independence Based on Position}

The Table 2 shows that analysis by position makes no significant differences in the distribution of public company and audit firm respondents, responses at either the $1 \%$ level or $5 \%$ level of significance. The intensity of belief noted in the previous section with respect to large firms and their ability to detect fraud appears to be only significant with account managers as opposed to financial managers and auditors. This suggests that account managers are more aware of the limitations of large firm audit practice at the transaction level. However, this result, whilst interesting, is not strongly supported by the evidence and is not pursued further in this research.

Table 2. Distribution of different statements regarding the size of audit firm based on position

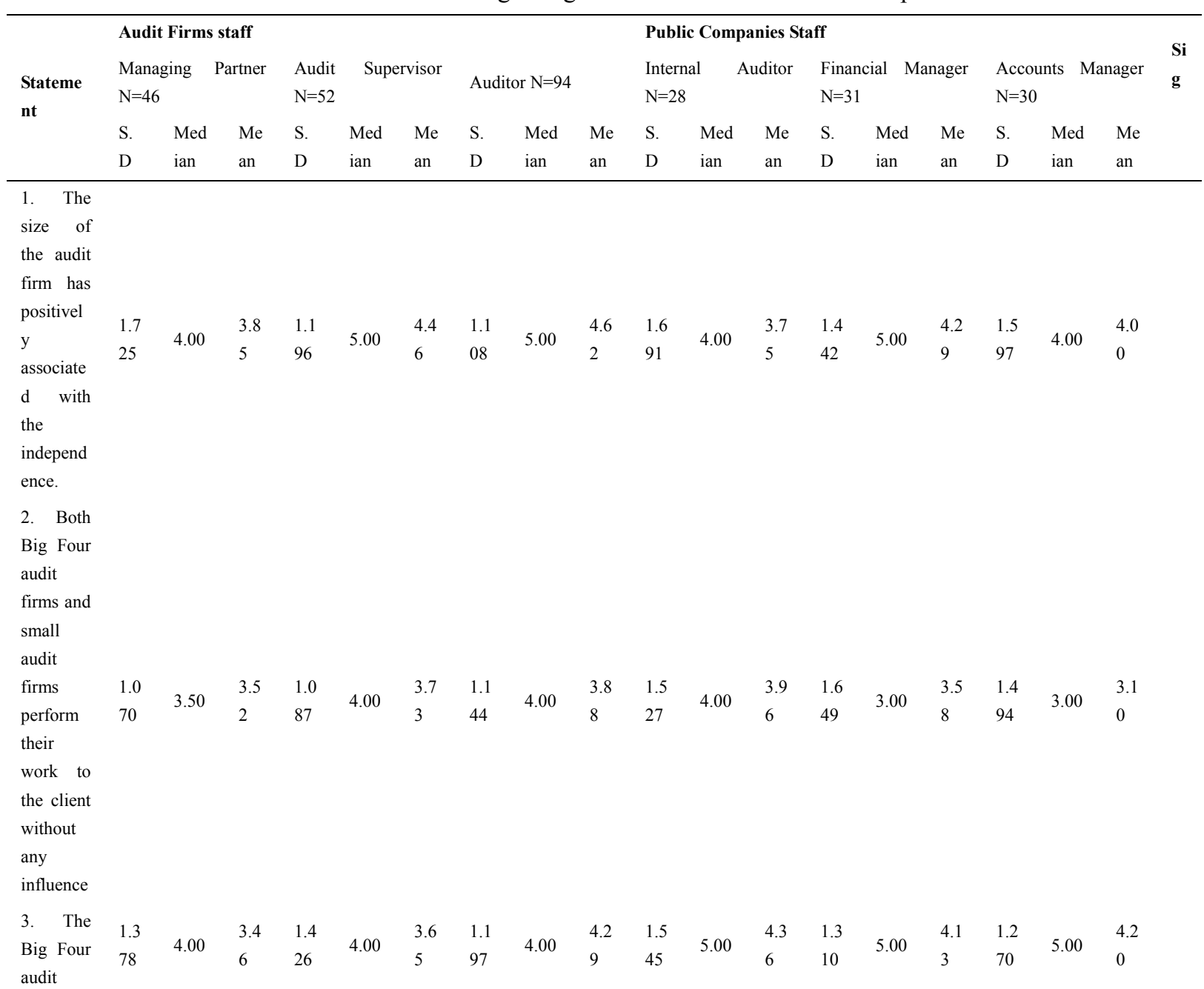




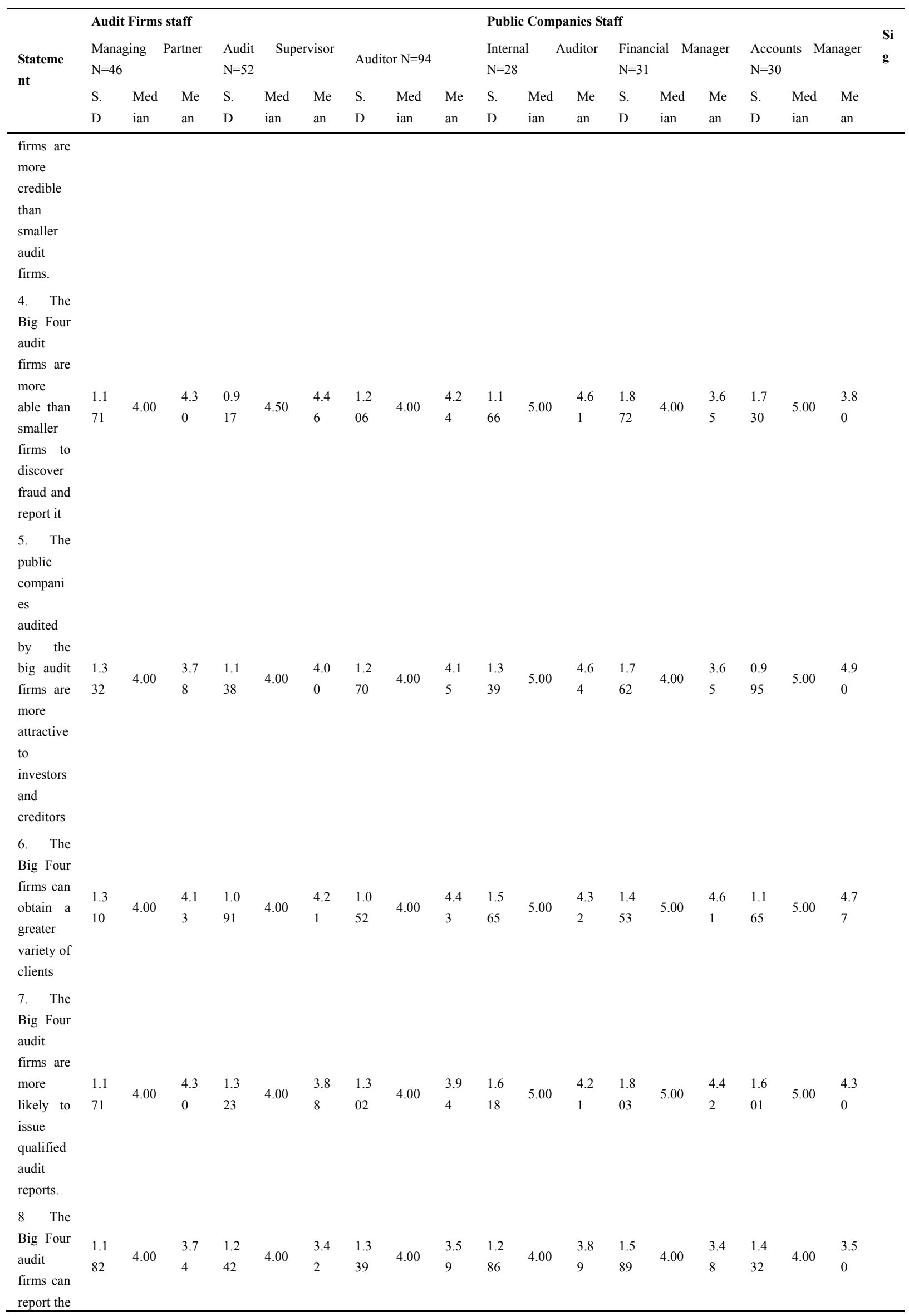




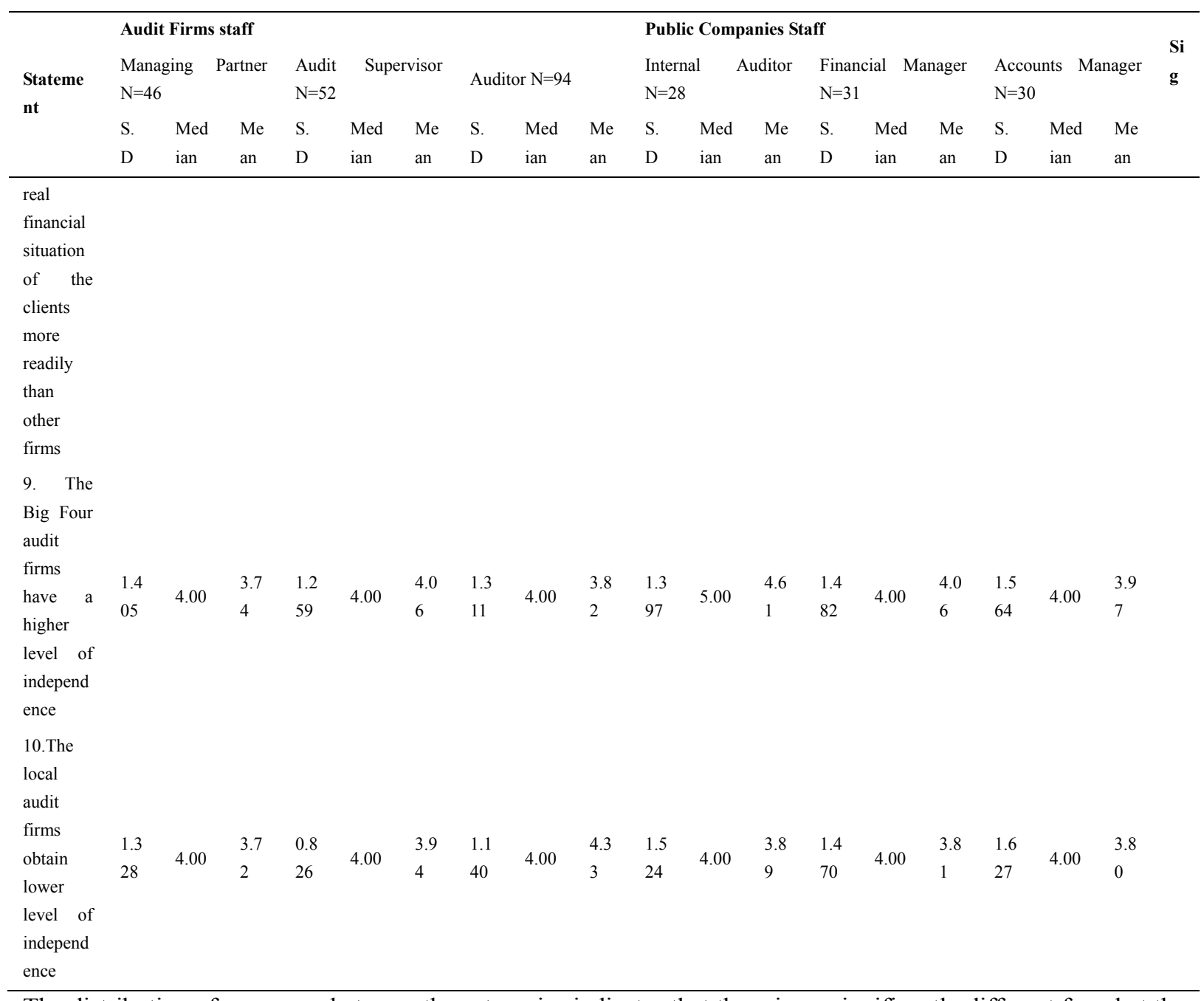

The distribution of responses between the categories indicates that there is no significantly different found at the $1 \%$ and $5 \%$ levels respectively (using Kruskal Wallis test).

\subsubsection{The Perceptions of Size of Audit Firm and Auditor Independence Based on Type of Audit Firm}

(Local Audit Firms, Local audit firm affiliated to Arabic and International audit firm, and Local audit firm affiliated to one of the big audit firms).

The analysis by types of audit firm (local audit firms, local affiliated to Arabic and international audit firm, and local audit firm affiliated to one of the big four audit firms), as reported in Table 6.9 shows two significant differences between the responses of the above types of audit firms at the $1 \%$ and $5 \%$ levels of significance, respectively, as measured by the Kruskal Wallis test.

The level of agreement with the statements, The Big Four audit firms are more likely to issue qualified audit reports, and the big audit firms have a higher level of independence more than other audit firms were significantly higher for local audit firm affiliated to one of the big four audit firm respondents than local audit firm respondents. This discrepancy in the responses of the sample of the above types of audit firm respondents perhaps indicates the main reasons why, in their opinion, the big firms are perceived as having a higher level of independence than non-Big audit firms. The reasons may be summarised as follows: first the big audit firms conduct more powerful and effective tests; second they are more credible; third they are more likely to issue qualified reports; fourth they can plan the audit process more effectively, fifth they can obtain a variety of clients which means they do not need to depend on single client. Lastly they are more risk averse to damaging their reputation as a result of a potential public scandal.

Generally, respondents' perceptions of the relationship between firm size and the level of auditor independence are consistent with the concept that the size of audit firms is positively associated with auditor independence, and the 
majority of the respondents in the last page of the questionnaire gave some reasons to support their views such as: 1) the big four audit firms have adequate financial resources, 2) the big four audit firms have qualified and skilful staff, 3) the big four have experienced staff, 4) the big four have staff with professional qualifications, 5) they have the ability to detect the errors, 6) they can obtain a variety of clients which means they do not need to depend on single client, which supports to some results in the literature (see, for instance: Abu Bakar et al., 2005; DeAngelo, 1981b; Gul, 1989; Kleinman et al., 1998; McKinley et al., 1985).

As previously the intensity of belief was examined by comparison of the mean and median. Only is question 7 was there an out of range response on the part of staff of affiliated audit firms suggestive of a degree of loyalty to the larger affiliate in its ability to issue qualified audit reports.

Table 3. Distribution of different statements regarding the size of audit firm based on type of audit firm

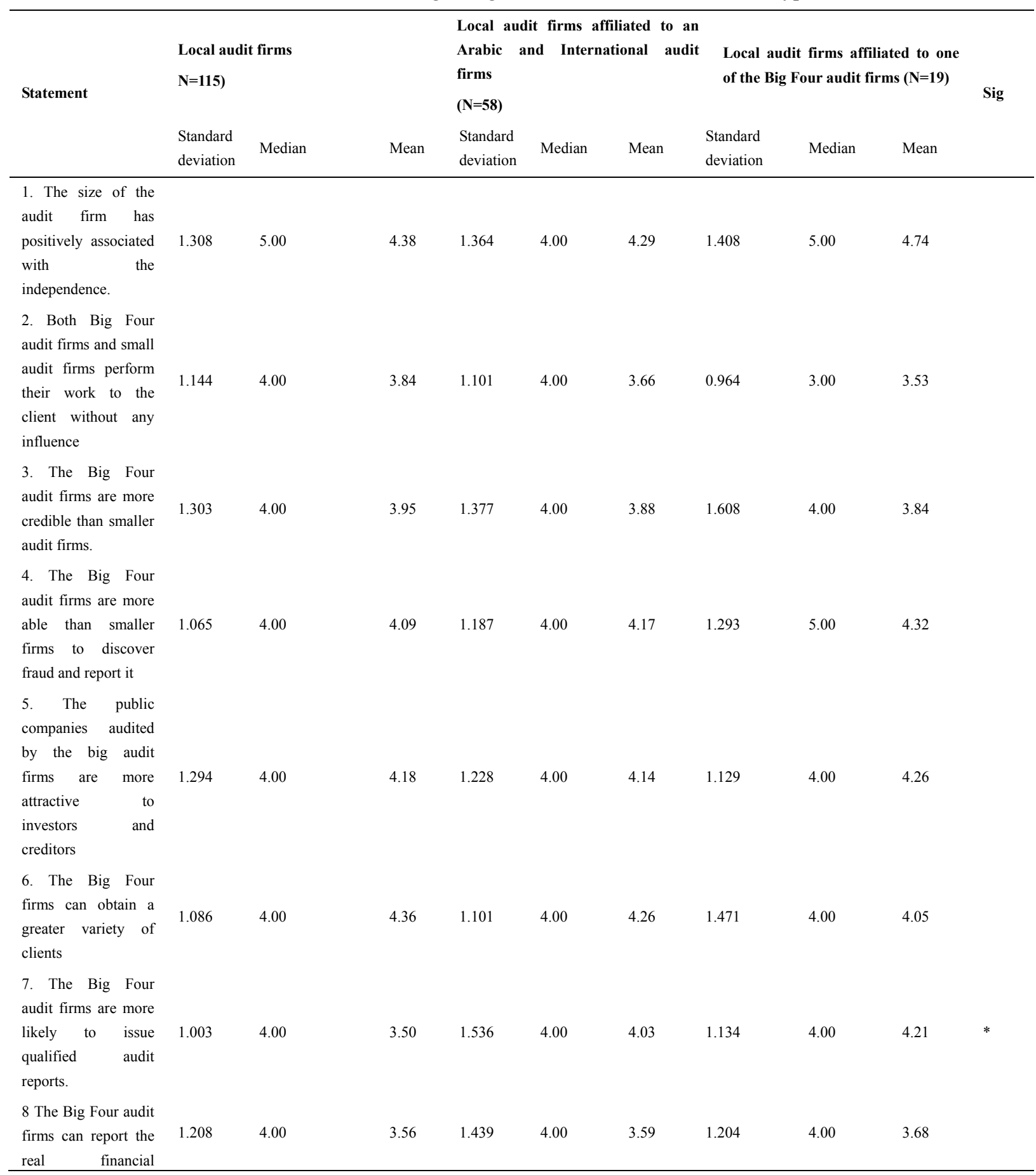




\begin{tabular}{|c|c|c|c|c|c|c|c|c|c|c|}
\hline \multirow[t]{2}{*}{ Statement } & \multicolumn{2}{|c|}{$\begin{array}{l}\text { Local audit firms } \\
\mathrm{N}=115 \text { ) }\end{array}$} & & $\begin{array}{l}\text { Local au } \\
\text { Arabic } \\
\text { firms }\end{array}$ & it firms a & $\begin{array}{l}\text { lated to } \\
\text { onal a }\end{array}$ & $\begin{array}{l}\text { Local } \\
\text { of the } \mathrm{F}\end{array}$ & $\begin{array}{l}\text { firms af } \\
\text { our audit }\end{array}$ & $\begin{array}{l}\text { ted to one } \\
\text { is }(N=19)\end{array}$ & \multirow[t]{2}{*}{ Sig } \\
\hline & $\begin{array}{l}\text { Standard } \\
\text { deviation }\end{array}$ & Median & Mean & $\begin{array}{l}\text { Standard } \\
\text { deviation }\end{array}$ & Median & Mean & $\begin{array}{l}\text { Standard } \\
\text { deviation }\end{array}$ & Median & Mean & \\
\hline \multicolumn{11}{|l|}{$\begin{array}{l}\text { situation of the } \\
\text { clients more readily } \\
\text { than other firms }\end{array}$} \\
\hline $\begin{array}{l}\text { 9. The Big Four } \\
\text { audit firms have a } \\
\text { higher level of } \\
\text { independence }\end{array}$ & 1.288 & 4.00 & 3.11 & 1.225 & 4.00 & 3.84 & 152 & 4.00 & 4.16 & $* *$ \\
\hline $\begin{array}{l}\text { 10.The local audit } \\
\text { firms obtain lower } \\
\text { level } \\
\text { independence }\end{array}$ & 1.058 & 4.00 & 4.22 & 1.249 & 4.00 & 3.81 & 1.177 & 4.00 & 4.05 & \\
\hline
\end{tabular}

\subsection{Qualitative Findings}

Table 4. Categories of organisations and the number of the interviewees and their position

\begin{tabular}{lllllllll}
\hline Organisation & \multicolumn{2}{l}{ public company } & \multicolumn{3}{c}{ audit firm } & \multicolumn{3}{c}{ LAAA } \\
position & $\begin{array}{l}\text { internal } \\
\text { auditor }\end{array}$ & $\begin{array}{l}\text { financial } \\
\text { manager }\end{array}$ & $\begin{array}{l}\text { accounts } \\
\text { manager }\end{array}$ & $\begin{array}{l}\text { audit } \\
\text { supervisor }\end{array}$ & $\begin{array}{l}\text { managing } \\
\text { partner }\end{array}$ & auditor & controller & Total \\
\hline $\begin{array}{l}\text { Number of } \\
\text { interviewees }\end{array}$ & 3 & 3 & 1 & 4 & 3 & 4 & 3 & 21 \\
\hline
\end{tabular}

In this section, the researcher attempted to elicit the interviewees' opinions regarding the ways to improve the level of the perceptions of auditor independence in the Libyan audit market. In the questionnaire survey results shown in table 1, about $64.6 \%$ of audit firm respondents and $65.2 \%$ of public company respondents either disagree or strongly disagree with the statement: An independent body should allocate audit clients to audit firms e.g. the $L A A A$. Similarly, the majority of the interviewees confirmed this result, and they observed that this can lessen competition in the audit market and that it was not adopted in developed countries. It will act as a deterrent to the ambitions of public companies to work with the audit firms which have a reputation in the market and good experience about the business type of those companies. However, most of the interviewees suggested that a representative from the LAAA should attend the Annual General Meetings of Shareholders to monitor the appointment of the external auditor, and ensure that was no manipulation by company management in selecting the external auditor.

The results of the questionnaire survey presented in, table 1 , revealed that $65.1 \%$ of audit firm respondents and $74.1 \%$ of public company respondents agreed with the statement: Public companies should disclose the amount of audit and NAS fees paid in the annual report. The majority of the interviewees supported this finding, and they agreed that the disclosure of the audit and NAS fees in the clients' financial reports would enhance auditor independence. Moreover, they pointed out that the disclosure of audit and NAS in the annual reports could tell the shareholders about the amount of fees which were given to the audit firm, and then they can discuss the level with the management if it seems too high. An audit supervisor of a local audit firm affiliated to a foreign audit firm remarked:

"I think the financial statements of the companies should include the amount of audit fees because that will help to remove any doubt if there is an inappropriate personal relationship between the auditor and management, (business under the table). Another important point is that the disclosure will give a complete picture to shareholders and the general public about those fees and then can discuss that with the management if they are not satisfied with the fees." 
In contrast, a minority of interviewees argued that the LAAA should establish regulations and procedures for audit firms to require them to disclose the kind and amount of NAS supplied to clients, as is the practice in developed countries.

Most interviewees believed that to improve the perception of auditor independence in the Libyan audit market the LAAA should adopt international auditing standards and accounting principles, since there are no specific local standards issued in Libya. Furthermore, most audit firms working in Libya adopt the accounting principles and auditing standards of the UK or the USA. An owner of a local audit firm pointed out:

"I think adopting the accounting principles and auditing standards of the UK or USA is better than issuing new local standards, because the majority of audit firms in Libya understand and have a very good idea about those standards."

Finally, a minority of interviewees criticised this idea and asked the LAAA to establish local standards like other developing countries, because the audit market in Libya is completely different to the market in the USA and the UK.

\section{Summary and Review of Findings}

The majority of responses from public companies staff and audit firms staff showed that the Libyan Association of Accountants and Auditors (LAAA) should adopt international auditing standards and accounting principles as an important step to improve the auditing profession and the perception of auditor independence in the Libyan audit market. Moreover, the majority of respondents had shown their dissatisfaction over allocating audit clients to audit firms by an independent body, such as the LAAA, perhaps because of respondents' desire to avoid audit firms thinking of establishing personal relationships with that body, which might have a negative effect on their reputation. Another reason for this is to give an opportunity to company management to choose the external auditor who can provide professional work and support its financial position by the auditing report. More important, the majority of public companies' and audit firms' responses revealed a preference for a law or regulation to be issued requiring public companies to disclose in their financial statements the amount of audit and non-audit service fees paid. This result recommends that this type of disclosure might identify, to interested parties, the type of association existing between the audit firm and the client.

These findings were confirmed by the majority of interviewees, especially the adoption of international accounting principles and auditing standards, rather than establishing local standards to improve auditing as a profession; it would at the same time help foreign audit firms to work in Libya without any professional difficulties. Furthermore, the interviewees showed dissatisfaction for an independent body such as the LAAA to allocate customers to audit firms, indicating that this might make the audit market in Libya less competitive, and that this action is not implemented in developed countries.

\section{References}

Abbott, A. (1983). Profession ethics. American Journal of Sociology, 856-885.

Abu Bakar, N., Rahman, A., \& Rashid, H. (2005). Factors influencing auditor independence: Malaysian loan $\begin{array}{lllll}\text { officers' perceptions. Managerial Auditing Journal, } & \text { 20(8), }\end{array}$ http://dx.doi.org/10.1108/02686900510619665

Bait-El-Mal, A. (2000). The role of management systems in Libya organizations: A Libyan development policy case study with special reference to the industrial sector. Unpublished Ph.D. dissertation.

Bait-El-Mal, M. M., Charles, S., \& Taylor, M. (1973). The development of accounting in Libya. International Journal of Accounting education and Research, 83-102.

Beatty, R. (1989). Audit reputation and the pricing of initial public offerings. Accounting Review, 64, 693-709.

Choi, J. J., Kim, X. L., \& Simunic, D. (2008). Audit Pricing, Legal Liability Regimes, and Big 4 Premiums: Theory and Cross-country Evidence. Contemporary Accounting Research. Forthcoming. http://dx.doi.org/10.1506/car.25.1.2

Chow, C., Kramer, L., \& Wallace, W. (1988). The environment of auditing. In the Second Decade, Sarasota, FL: American Accounting Association, 19-46.

Clarkson, P. M., \& Simunic, A. (1994). The association between audit quality, retained ownership and firm-specific risk in US vs. Canadian IPO markets'. Journal of Accounting and Economics, 17, 207-228. http://dx.doi.org/10.1016/0165-4101(94)90010-8

Cohen, L., \& Manion, L. (1980). Research methods in education (1st ed.). London: Longman. 
Collis, J., \& Hussey, R. (2003). Business research (2nd ed.). Palgrave Macmillan.

Davidson, R., \& Neu, D. (1993). A note on the association between audit firm size and audit quality. Contemporary Accounting Research, 9(2), 479-488. http://dx.doi.org/10.1111/j.1911-3846.1993.tb00893.x

DeAngelo, L. E. (1981a). Auditor Size and Audit Quality. Journal of Accounting and Economics, 3, 183-199. http://dx.doi.org/10.1016/0165-4101(81)90002-1

DeAngelo, L. E. (1981b). Auditor independence, "low balling", and disclosure regulation. Journal of Accounting and Economics, 113-127. http://dx.doi.org/10.1016/0165-4101(81)90009-4

Denscombe, M. (2001). Good research guide: For small-scale research projects. Open University Press. Buckingham, UK.

Dye, R. (1993). Auditing standards, legal liability and auditor wealth. Journal of Political Economy, 101, 887-914. http://dx.doi.org/10.1086/261908

Feltham, G., Hughes, J., \& Simunic, D. (1991). Empirical assessment of the impact of auditor quality on the valuation of new issues. Journal of Accounting and Economics, 14, 375-399. http://dx.doi.org/10.1016/0165-4101(91)90009-D

Ferdinand, A., Bikki, J., \& Gopal, V. (2007). Auditor Independence: Evidence on the Joint Effect of Auditor Tenure and Non-audit fees. Practice Theory, 26(2), 117-142.

Goldman, A., \& Barklev, B. (1974, October). The auditor-firm conflict of interests: Its implications for independencer. In B. Barlev (Ed.), The Accounting Review (pp. 707-718).

Gul, F. A. (1991). Size of audit fees and perceptions of auditors' ability to resist management pressure in audit conflict situations'. Abacus, 27(2), 162-173. http://dx.doi.org/10.1111/j.1467-6281.1991.tb00264.x

Higson, A. (2003). Corporate financial reporting: Theory and practice. Sage Publications Ltd.

Hillison, W., \& Kennelly, M. (1988). The economics of non-audit services, Accounting Horizons, 2, 32-40.

Humphrey, C. (1997). Debating audit expectations. Current issues in auditing (3rd ed., pp. 3-30). London: Paul Chapman.

Jackson-Heard, M. F. (1987). The Effect of Audit Committee and Other Selected Factors on the Perception of Auditor Independence. New York University: $\mathrm{PhD}$ thesis (Unpublished).

Jensen, M. C., \& Meckling, W. H. (1976). Theory of the Firm: Managerial Behaviour, Agency Costs and Ownership Structure. Journal of Financial Economics, 3(4), 305-360. http://dx.doi.org/10.1016/0304-405X(76)90026-X

Khorwatt, E. (2006). The Attitude of Libyan Auditors to Inherent and Control Risk Assessments. Unpublished. $\mathrm{PhD}$, dissertation The Manchester Metropolitan University UK.

Kilani, K. A. (1988). The evaluation and status of accounting in Libya. Unpublished Ph.D. dissertation. Hull. UK.

Kothari, S., Lys, T., Smith, C., \& Watts, R. (1988). Auditor liability and information disclosure. Journal of Accounting, Auditing and Finance, 3, 307-340.

Lennox, C. (1999). Non-audit fees, disclosure and audit quality. European Accounting Review, 8(2), 239-252. http://dx.doi.org/10.1080/096381899336014

Lys, T., \& Watts, R. (1994). Lawsuits against auditors. Journal of Accounting Research, 32, 65-93. http://dx.doi.org/10.2307/2491440

Mahmud, M. (1997). Accounting and economic development of oil and gas in Libya. Unpublished PhD: dissertation. Dundee University of Dundee, UK

Mautz, R. K., \& Sharaf, H. (1961). The Philosophy of Auditing. American Accounting Association.

McKinley, S., Pany, K., \& Reckers, P. (1985). An examination of the influence of CPA firm type, size and MAS provision on loan officer decisions and perception. Journal of Accounting Research, 887-896. http://dx.doi.org/10.2307/2490846

McLennan, A., \& Park, I. (2003). The market for liars: Reputation and auditor honesty'. Discussion Paper No. 587 The Institute of Social and Economic Research, Osaka University.

Palmrose, Z. V. (1986a). Audit Fees and Auditor size: Further Evidence. Journal of Accounting Research, 24(1), 
97-110. http://dx.doi.org/10.2307/2490806

Palmrose, Z. V. (1986b). The effect of non-audit services on the pricing of audit services: Further evidence'. Journal of Accounting Research, 24(2), 405-411. http://dx.doi.org/10.2307/2491144

Palmrose, Z. V. (1988). An analysis of auditor litigation and audit service quality. Accounting Review, 63(1), $55-73$.

Palmrose, Z. V. (1989). The Relation of Audit Contract Type to Audit Fees and Hours. The Accounting Review, 64(3), 488-499.

Pearson, M. A. (1980). A profile of the "big eight" independence position'. Baylor Business Studies, 11, 7-27.

Richard, C. (2006, July). Why an auditor can't be competent and independent: A French case study. European Accounting Review, 15(2), 153-179. http://dx.doi.org/10.1080/09638180500104832

Saunders, M., Lewis, P., \& Thornhill, A. (2007). Research methods for business students (3rd ed.). Prentice Hall.

Saunders, M., Lewis, P., \& Thornhill, A. (2009). Research methods for business students (5th ed.). UK: Pearson Education Limited.

Sekaran, U. (2003). Research Methods for Business: A Business: A Skill Building Approach (4th ed.). New York: John Wiley Inc.

Shawn, M., \& Dana, H. (2008). The Impact of Non-audit Services Fee Levels on Investors' Perception of Auditor Independence. Behavioral Research in Accounting, 20(1), 31-44. http://dx.doi.org/10.2308/bria.2008.20.1.31

Shockley, R. A. (1981). Perceptions of Auditors' Independence: An Empirical Analysis. The Accounting Review, 785-800.

Shockley, R. A. (1982). Perceptions of auditor independence: A conceptual model. Journal of Accounting, Auditing and Finance, 5(2), 126-143.

Watts, R. L., \& Zimmerman, J. L. (1983). The markets for independence and independent auditor. Working Papers University of Rochester.

Zikmund, W. G. (2000). Business Research Methods (6th ed.). Fort Worth: Dryden Press.

\section{Copyrights}

Copyright for this article is retained by the author(s), with first publication rights granted to the journal.

This is an open-access article distributed under the terms and conditions of the Creative Commons Attribution license (http://creativecommons.org/licenses/by/3.0/). 